\title{
Compatibility of Azospirillum brasilense and Pseudomonas fluorescens in growth promotion of groundnut (Arachis hypogea $\mathrm{L}$.)
}

\author{
ANDHARE A. PRASAD and SUBRAMANIAN BABU \\ School of Bio Sciences and Technology, VIT University, Vellore 632014, India \\ Manuscript received on September 13, 2016; accepted for publication on November 28, 2016
}

\begin{abstract}
We attempted to study the compatibility among plant beneficial bacteria in the culture level by growing them near in the nutrient agar plates. Among all the bacteria tested, Rhizobium was found to inhibit the growth of other bacteria. From the compatible group of PGPR, we have selected one biofertilizer (Azospirillum brasilense strain TNAU) and one biocontrol agent (Pseudomonas fluorescens strain PF1) for further studies in the pot culture. We have also developed a bioformulation which is talc powder based, for individual bacteria and mixed culture. This formulation was used as seed treatment, soil application, seedling root dip and foliar spray in groundnut crop in vitro germination conditions. A. brasilense was found to enhance the tap root growth and $P$. fluorescens, the lateral root growth. The other growth parameters like shoot growth, number of leaves were enhanced by the combination of both of the bacteria than their individual formulations. Among the method of application tested in our study, soil application was found to be the best in yielding better results of plant growth promotion.
\end{abstract}

Key words: Azospirillum brasilense, groundnut, PGPR, Pseudomonas fluorescens.

\section{INTRODUCTION}

The rhizosphere is a highly dynamic front for interactions between roots and pathogenic and beneficial soil microbes, invertebrates, and root systems of competitors (Hirsch et al. 2003). However, because plant roots are hidden belowground, many of the interesting phenomena in which they are involved have remained largely unnoticed. The root-microbe interactions has been classified as positive (mediated largely by PGPRplant growth promoting rhizobacteria) and negative

Correspondence to: Subramanian Babu

E-mail: babu.s@vit.ac.in associations (pathogens). A third category of neutral associations is also recognized. Plant growthpromoting rhizobacteria (PGPR) are beneficial bacteria that colonize plant roots and enhance plant growth by a wide variety of mechanisms. The use of PGPR is steadily increasing in agriculture and offers an attractive way to replace chemical fertilizers, pesticides, and supplements (Ashrafuzzaman et al. 2009).

Although individual PGPR strains have demonstrated to perform well under specific crop-soil environments, many microbes are recommended for a single crop. For example, rice farming has been advocated with use of PGPR 
like Azospirillum, Azotobacter, Phosphobacteria and $P$. fluorescens for various purposes. Recently, Bacillus subtilis has been proved effective against many pathogens of rice and also an effective endophyte to induce systemic resistance. Hence farmers are left with applying the biofertilizer and biocontrol agents separately and multiple times during crop growth stage. All the microbes have to prove effective in colonization of the plant roots for efficient function under natural soil conditions. Compatibility between the PGPR microbes to colonize the root system without inhibiting each other is a pre-requisite for success of using multiple microbes in a crop field.

The use of mixed cultures of beneficial microorganisms as soil inoculants is based on the principles of natural ecosystems which are sustained by their constituents; that is, by the quality and quantity of their inhabitants and specific ecological parameters, i.e., the greater the diversity and number of the inhabitants, the higher the order of their interaction and the more stable the ecosystem (Higa 1994). The mixed culture approach is simply an effort to apply these principles to natural systems such as agricultural soils, and to shift the microbiological equilibrium in favor of increased plant growth, production and protection (Higa 1994).

Not much work have been done on the compatibility of the PGPR bacteria with each other except for some mixed formulations involving two biocontrol agents or two biofertilizers. Direct field trials using mixed formulations have resulted in increased yield and disease resistance, than individual stains, in crop plants and have been recorded. However, the relative contribution of each of the strain in the overall performance of the crops is largely unknown (Babu 2011). With this background, we attempted to study the compatibility among the commercially available bioinoculant bacteria used in South Indian agriculture. Based on compatibility exhibited in culture, we evaluated a two-bacterial mixture viz., A. brasilense and $P$. fluorescens for growth promotion in groundnut.

\section{MATERIALS AND METHODS}

\section{MICROBIAL CULTURES}

Four biofertilizers viz., Rhizobium (CRR6/CPR9), Azotobacter (NB-1), Azospirillum (Az-204), Phosphobacteria (Bacillus megaterium, TNAU1) and two biocontrol agents viz., Pseudomonas fluorescens (PF-1) and Bacillus subtilis (Bbv57) were obtained as commercial talc powder based formulation from Tamil Nadu Agricultural University, Coimbatore, India. One gram of the formulation was suspended in $5 \mathrm{~mL}$ of sterile water overnight and the supernatant was serially diluted and plated onto nutrient agar plates by spread plate method. Single colonies were isolated and maintained as pure cultures on nutrient agar slants for further studies.

\section{COMPATIBILITY TEST IN CULTURE}

Bacterial cultures were streaked on nutrient agar plates in such a way that for every single bacterial culture in the centre of the plate, other cultures are streaked radiating from the centre. The plates were incubated at $37^{\circ} \mathrm{C}$ for $48 \mathrm{~h}$ and the zone of inhibition was observed and recorded.

PREPARATION OF AZOSPIRILLUM AND P. fluorescens MIXED FORMULATION

\section{A. brasilense (strain TNAU) and $P$. fluorescens} (strain PF1) were grown in Doereiner's malic acid broth with $\mathrm{NH}_{4} \mathrm{Cl}$ and King's B broth, respectively for 4 days in a rotary shaker at $200 \mathrm{rpm}$ until the cell population reached $10^{10}$ to $10^{11} \mathrm{cfu} \mathrm{mL}^{-1}$. Talc based carrier material was prepared as described by Vidhyasekaran et al. (1997) with $20 \mathrm{~g} \mathrm{Kg}^{-1}$ carboxy methyl cellulose and $15 \mathrm{~g} \mathrm{Kg}^{-1}$ calcium carbonate. About $200 \mathrm{~mL}$ of the bacterial culture was used per $\mathrm{Kg}$ of the carrier material in the case of single culture. For the mixed culture, $100 \mathrm{~mL}$ each of 
the bacterial cultures were mixed. The talc based formulation thus prepared was air dried in culture room and packed aseptically in sterile polythene bags.

\section{TREATMENTS}

Garden soil obtained from nursery, VIT University, Vellore, India was sterilized intermittently for two days each time for one hour and filled in plastic pots of $5 \times 9 \mathrm{~cm}$. Groundnut seeds of cultivated variety TKM9 obtained from Tamil Nadu Agricultural University, Coimbatore, India was used in the study. The following four different treatments were performed. Seed treatment was done by mixing the seeds with bacterial formulations (singly and mixed) at the rate of $10 \mathrm{~g}$ per $\mathrm{Kg}$ of seeds with sterile water to form a uniform slurry coat on the seeds. The seeds were incubated at room temperature for one hour before sowing. For soil treatment, $10 \mathrm{~g}$ of formulation was added per $\mathrm{Kg}$ of soil and mixed before sowing. Seedling root dip treatment was done on ten days old seedlings. Seedlings were removed from pots and dipped in $2 \%$ suspension of the bacterial formulations for two hours and transplanted in fresh pots. Foliar spray was done with $2 \%$ suspension of bacterial formulations on 10 day old seedlings using a hand sprayer. For every treatment method, untreated control was maintained.

\section{GROWTH OBSERVATIONS}

Two weeks after treatment, observations were made on overall appearance of seedlings, color of leaves, number of leaves, number of branches, root length (tap root and lateral roots) and shoot length.

\section{STATISTICAL ANALYSIS}

The data on growth parameters were analyzed statistically using student's t-test.

\section{RESULTS}

In culture compatibility studies, each plate carried all the test bacteria with one bacterial strain in the centre and other bacteria streaked radiating from the centre. The results of the experiment are presented in Figure 1a. In all the plates, Rhizobium showed growth inhibition of other bacteria irrespective of its position in the plate (centre or radiating from centre). Figure $1 \mathrm{~b}$ represents the closer view of zone of inhibition exhibited by Rhizobium on other bacteria.

The root and shoot growth of groundnut treated with the individual and mixed formulations by soil application is presented in Figure 2a. The growth of roots is significantly higher in the mixed formulation treatment compared to individual bacteria and the untreated control. Figure $3 \mathrm{a}$ represents the root and shoot growth of the plants under seed treatments. Seed treatment also resulted in the enhanced root growth in mixed formulation treatment than individual bacteria and the untreated control. Seedling root dip method for the artificial inoculation of groundnut plants with individual and mixed PGPR resulted in no visible significant difference in the root or shoot growth (Figure 4a). The root and shoot growth were similar in all treatments and were on par with untreated control. Foliar spray treatment also produced similar results as like seedling root dip method and no visible differences could be observed in the root and shoot growth when the individual and mixed application of the bacteria were compared with untreated control (Figure 5a).

In the soil treatment experiment (Figure $2 \mathrm{~b}$, Tables I-V), the average shoot length of the seedlings in mixed bacterial treatment, individual P. fluorescens and control were on par. A. brasilense recorded less shoot length of the seedlings. Tap root length was more in A. brasilense and significantly higher than other treatments and control. Lateral root length was more in the case of mixed bacteria 
a
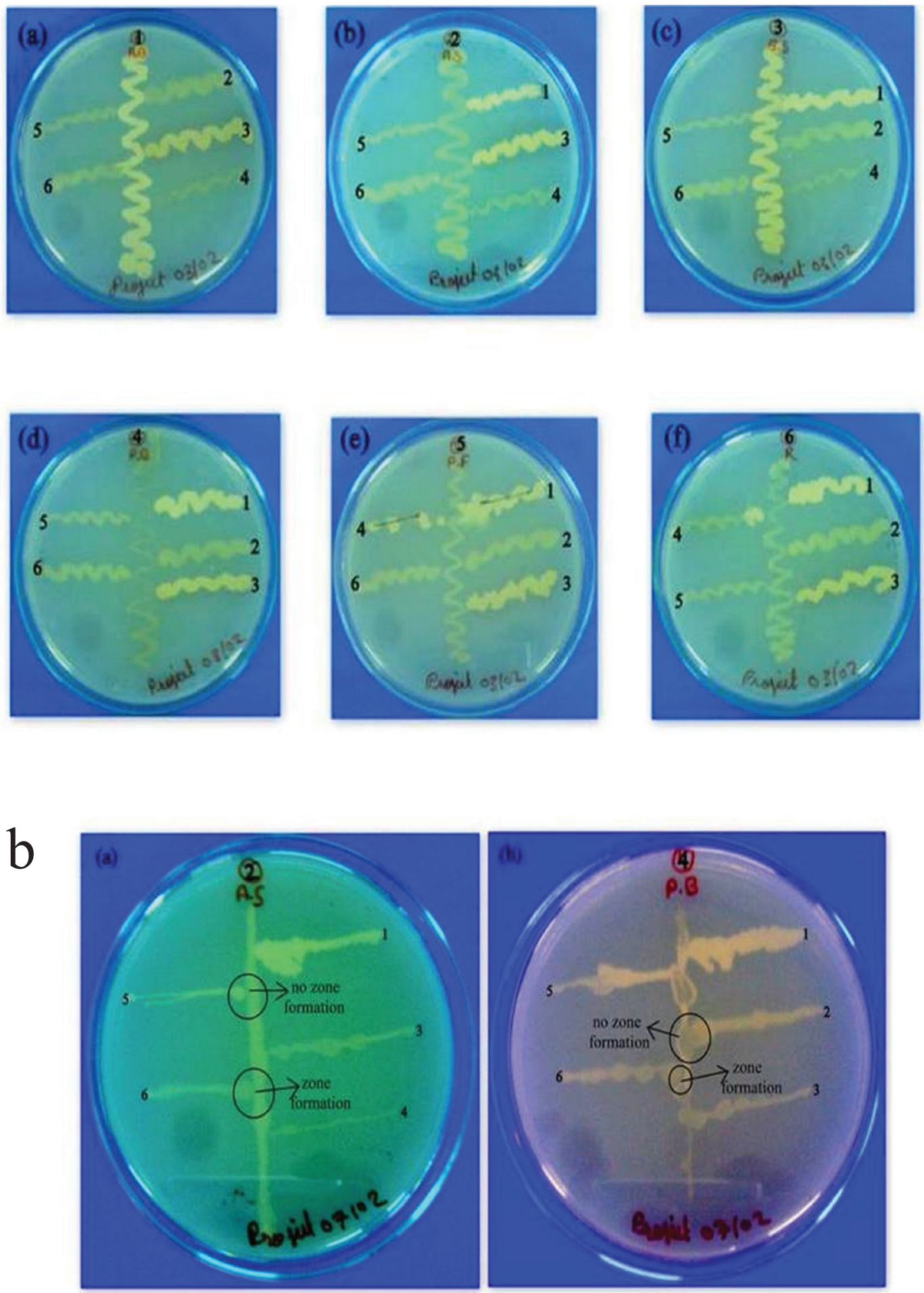

Figure 1 - Cultural compatibility test of rhizosphere inhabiting beneficial bacteria.

a. Compatibility among six different bacteria.

b. Growth inhibition exhibited by Rhizobium on other bacteria.

1. Azotobacter 2. Azospirillum 3. Bacillus subtilis 4. Phosphobacteria 5. Pseudomonas fluorescens 6. Rhizobium. 

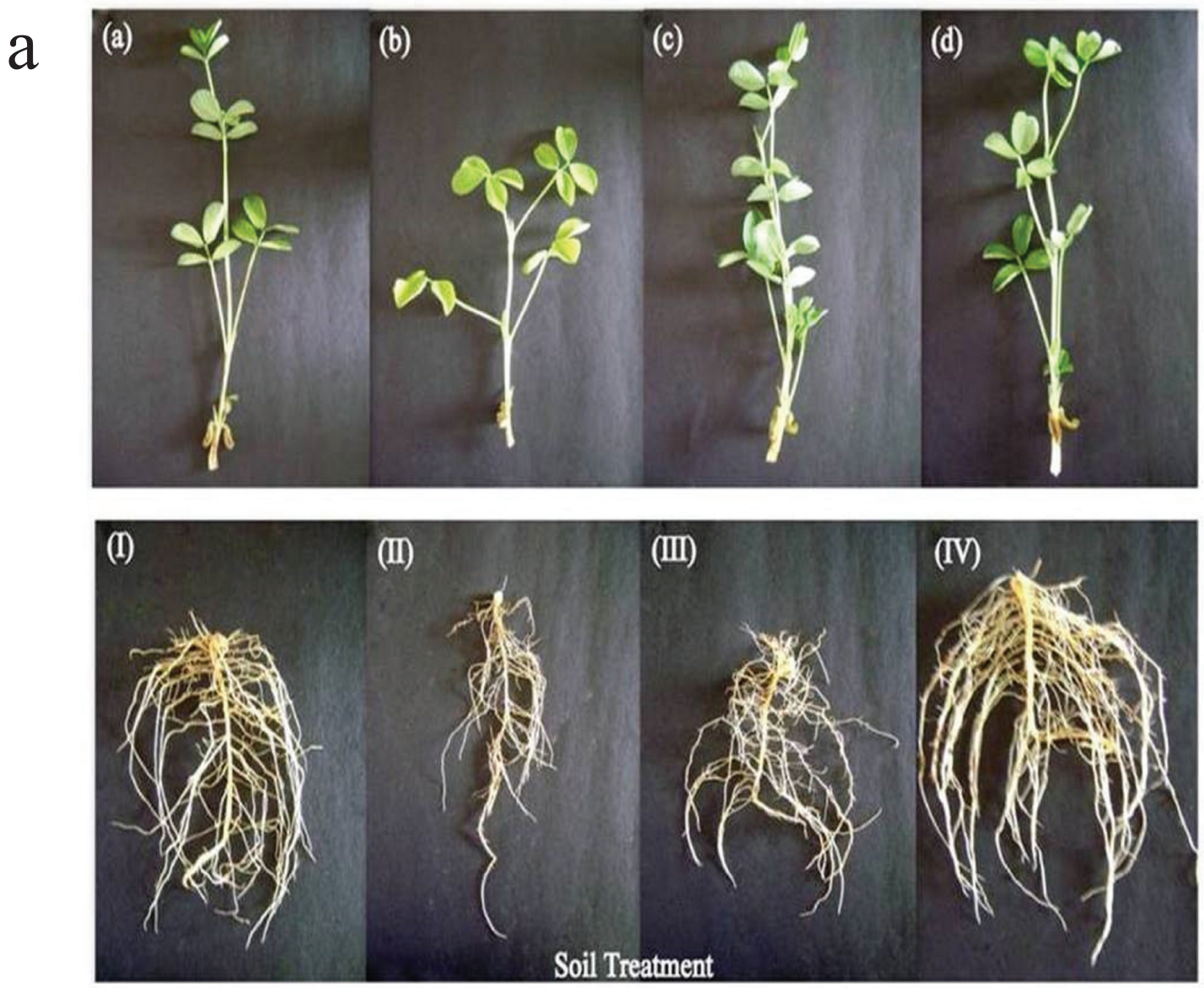

b
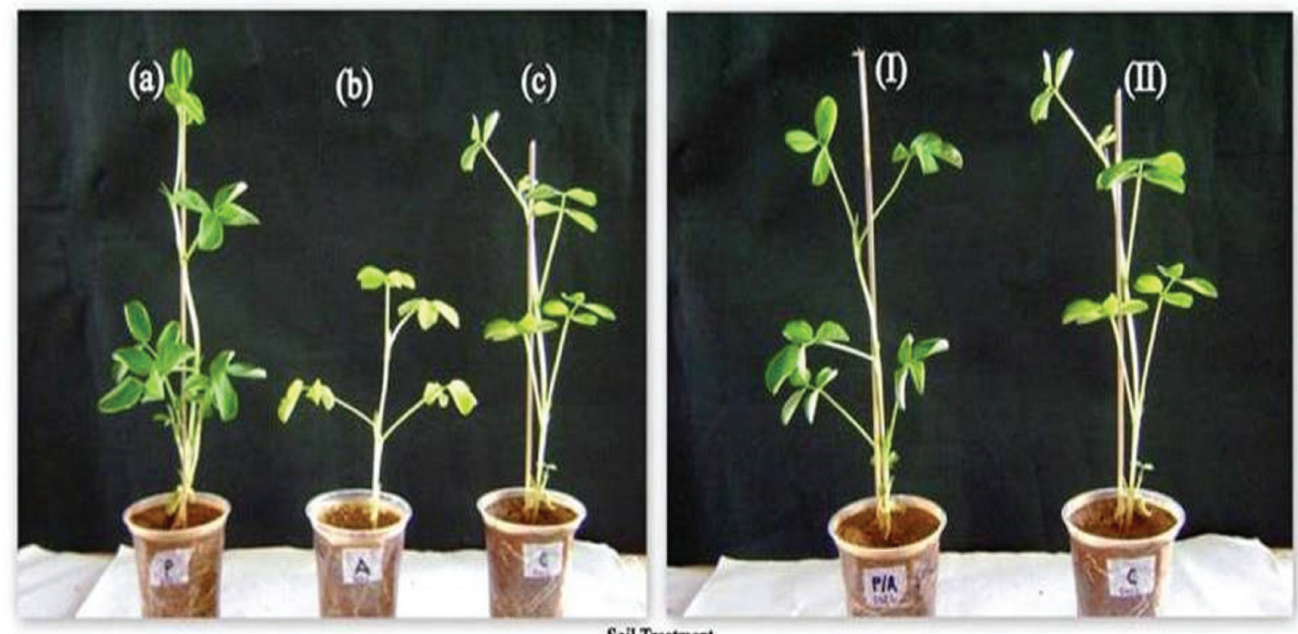

Soil Treatment

Figure 2 - Growth of groundnut plants under soil application of PGPR.

a. Root and shoot growth of groundnut under soil application of PGPR.

(a) and (I) - Control; (b) and (II) - A. brasilense; (c) and (III) - P. fluorescens; (d) and (IV) - A. brasilense and P. fluorescens.

b. Groundnut plants after soil application with PGPR.

(a) - P. fluorescens; (b) - A. brasilense; (c) - Control; (I) - A. brasilense and P. fluorescens; (II) - Control. 
then individual bacteria. The number of leaves was highest in the plants treated with individual $P$. fluorescens than its combination with $A$. brasilense. Color of the leaves were dark green in P. fluorescens treatments irrespective of either individual culture or mixed with $A$. brasilense. The overall appearance of the plants recorded better growth and healthy conditions in the plants treated with both bacteria (Tables I-V). In seed treatment experiment (Figure 3 b, Tables I-V), the shoot length was recorded higher in the plants treated with both the bacteria. Tap root growth was maximum in $A$. brasilense treatment. Compared to control, the tap root growth was significantly higher in all treatments including individual and mixed bacteria. The lateral root growth was higher in the plants treated with both bacteria. All other treatments were on par with the control. Lateral root growth was recorded highest in the treatment of formulation containing both bacteria and all other treatments were on par with the control in inducing lateral root growth. The number of leaves and branches were more in the treatment with $P$. fluorescens as single strain formulation than the mixed formulation or $A$. brasilense. In seedling root dip treatment (Figure 4b, Tables I-V), the shoot length recorded in $P$. fluorescens individual strain containing formulation was higher than its combination with $A$. brasilense or the individual A. brasilense. However, the tap root growth was significantly higher in A. brasilense treatment than any other treatment. Number of leaves and branches were more in mixed formulation treatment when applied as seedling root dip. The color of the leaves and overall plant growth was better in the $P$. fluorescens treatment individually and in combination with $A$. brasilense.

In foliar spray experiment (Figure 5b, Tables $\mathrm{I}-\mathrm{V})$, the shoot length recorded was higher in the $P$. fluorescens individual strain. Other treatments failed to show drastic differences from untreated control. Tap root length was the highest in P. fluorescens treatment when it was used as individual strain.
Lateral root length was higher in both individual $P$. fluorescens and its combination with $A$. brasilense. Number of leaves were higher in $A$. brasilense treatment than any other treatment. Similar results were obtained for number of branches also. The color of the leaves and overall growth of the plants were better in $P$. fluorescens and the mixed formulation of $P$. fluorescens and A. brasilense.

$P$. fluorescens performed well in seedling root dip method than other treatments in inducing more shoot growth. Tap root growth is significantly influenced by $A$. brasilense under all treatments including seed, soil and seedling root dip. However, A. brasilense failed to show significant differences in the tap root growth induction when it was used as foliar spray. A. brasilense performed better in enhancing tap root growth when it is used as individual inoculum than when compared to its mixed inoculums along with $P$. fluorescens. Lateral growth of roots is supported by the combination of A. brasilense and P. fluorescens than their individual formulations. This combination recorded significantly higher lateral growth of roots in soil treatment experiment and seed treatment experiment. However, the lateral growth of roots was the highest in $P$. fluorescens individual strain formulation when used in seedling root dip methods. The effect of $P$. fluorescens as single strain or its mixture with A. brasilense recorded similar results in induction of lateral growth of roots under foliar spray conditions. Soil treatment was found to be the best for the performance of $P$. fluorescens as individual bacteria and also its combination with A. brasilense in enhancing the number of leaves produced by groundnut. In foliar spray experiment, however, A. brasilense recorded highest number of leaves compared to P. fluorescens or mixed formulation. 


\section{DISCUSSION}

In our study, among the different rhizosphere microbes tested for their compatibility in culture growth, the Rhizobium species was found to inhibit the growth of other bacteria as evident from the zone of inhibition observed in the plates. All other microbes viz., Azospirillum, Azotobacter, Phosphobacteria, P. fluorescens and B. subtilis were compatible with each other. These results have made us to choose the best two candidate bacteria for pot culture studies. We have chosen $A$. brasilense (biofertilizer) and P. fluorescens for the testing of their compatibility in the formulation. Choice of bacteria for further studies is based on combination of one biocontrol agent and one biofertilizer among the compatible species.

A. brasilense individual strain formulation resulted in increased tap root growth when compared to P. fluorescens and control. It is interesting that the tap root growth was not enhanced by Azospirillum when it is present in combination with $P$. fluorescens in the mixture. All other parameters like shoot growth, lateral roots, number of leaves etc. were highly influenced by the activity of $P$. fluorescens. When P. fluorescens is in combination with $A$. brasilense, the impact on all these aforesaid parameters was more.

Comparing the method of application of the formulations to groundnut, soil treatment was found to be the best yielding better results in all growth parameters tested. Next to soil treatment, seed treatment was found better. Foliar spray failed to produce any significant influence on growth parameters of groundnut when compared to control implicating that these bacteria can perform well when they are in their native environment, the soil. Seedling root dip was not found to be an optimal method of application of bioformulations and we found it not surprising because, groundnut is not a transplanted crop but it is directly sown in the field conditions.
Moreover, since $A$. brasilense is a biofertilizer commercially used in agriculture for all the field crops, its role in tap root growth is validated in our study. However, for the growth of lateral roots, $P$. fluorescens has to play a role as evident from our study. Since root growth is the most significant parameter for groundnut yield, our study clearly demonstrates that the combination of $A$. brasilense and $P$. fluorescens in a more optimal mix can enhance root growth in groundnut and in turn yield of groundnut.

PGPR like Pseudomonas are of particular interest because of the intrinsic ability of certain strains to colonize the rhizosphere at a high density, to compete successfully with other microbes, and to produce secondary metabolites involved in plant growth stimulation and induced systemic resistance to biotic stress posed by pests and pathogens. Aggressive colonization and the ability to compete with resident microbes are prerequisites for the establishment of effective plant growth promoting and biocontrol strains. The efficient inoculant should survive in the rhizosphere, make use of nutrients exuded by the plant, proliferate, be able to efficiently colonize the entire root system and be able to compete with endogenous microbes. Inadequate biocontrol in field experiments has often been correlated to poor root colonization (Bloemberg and Lugtenberg 2001). Identification of the genes and traits involved in the processes of inoculation and root colonization will give a more detailed insight into plant-microbe interactions and lead to more efficient application of inoculant strains. For example, P. fluorescens genes that are specifically expressed in the rhizosphere (i.e. rhi genes) have been identified. Some of the genes were reported to have a role in nutrient acquisition, stress response, or secretion. Many root colonization genes and traits from Pseudomonas have been identified.

Several rhizosphere bacteria have been reported to possess more than one desirable 

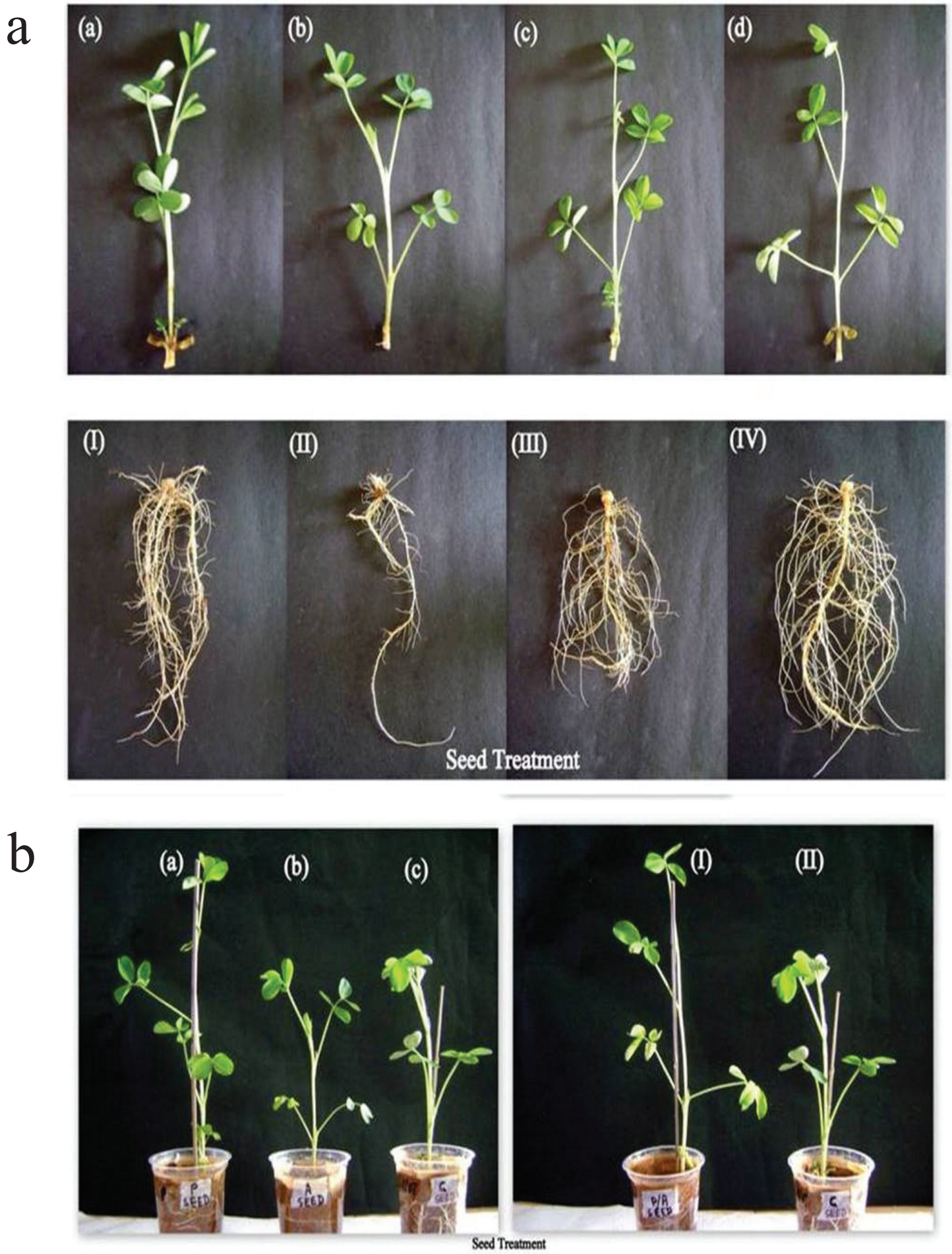

Figure 3 - Growth of groundnut plants under seed treatment with PGPR.

a. Root and shoot growth of groundnut under seed treatment with PGPR.

(a) and (I) - Control; (b) and (II) - A. brasilense; (c) and (III) - P. fluorescens; (d) and (IV) - A. brasilense and P. fluorescens.

b. Groundnut plants after seed treatment with PGPR.

(a) - P. fluorescens; (b) - A. brasilense; (c) - Control; (I) - A. brasilense and P. fluorescens; (II) - Control. 
TABLE I

Effect of methods of application of single and mixed PGPR on the shoot growth of groundnut plants.

\begin{tabular}{|c|c|c|c|c|}
\hline \multirow{2}{*}{$\begin{array}{l}\text { PGPR } \\
\text { treatment }\end{array}$} & \multicolumn{4}{|c|}{ Shoot growth (in mm) } \\
\hline & Soil application & Seed treatment & Seedling root dip & Foliar spray \\
\hline Control & $25.5 \pm 0.56^{\mathrm{b}}$ & $20.7 \pm 0.50^{\mathrm{b}}$ & $24.2 \pm 0.20^{\mathrm{b}}$ & $19.6 \pm 0.32^{\mathrm{a}}$ \\
\hline A. brasilense & $20.5 \pm 0.61^{\mathrm{a}}$ & $19.4 \pm 0.21^{\mathrm{a}}$ & $25.6 \pm 0.32^{\mathrm{c}}$ & $21.0 \pm 0.15^{\mathrm{b}}$ \\
\hline P. fluorescens & $27.7 \pm 0.38^{\mathrm{c}}$ & $23.6 \pm 0.25^{\mathrm{c}}$ & $28.5 \pm 0.30^{d}$ & $24.4 \pm 0.25^{\mathrm{d}}$ \\
\hline $\begin{array}{l}\text { A. brasilense + } \\
\text { P. fluorescens }\end{array}$ & $25.4 \pm 0.20^{\mathrm{b}}$ & $24.3 \pm 0.32^{\mathrm{d}}$ & $22.6 \pm 0.30^{\mathrm{a}}$ & $22.6 \pm 0.32^{\mathrm{c}}$ \\
\hline
\end{tabular}

Average of three replicates; $\pm=\mathrm{SE}$; Differences between control and treated significant at $\mathrm{p}=0.01$ (Student's t-test) where superscript of control and treated are different; where superscript same, difference insignificant.

TABLE II

Effect of methods of application of single and mixed PGPR on the tap root growth of groundnut plants.

\begin{tabular}{|c|c|c|c|c|}
\hline \multirow{2}{*}{$\begin{array}{l}\text { PGPR } \\
\text { treatment }\end{array}$} & \multicolumn{4}{|c|}{ Tap root growth (in $\mathbf{m m}$ ) } \\
\hline & Soil application & Seed treatment & Seedling root dip & Foliar spray \\
\hline Control & $10.4 \pm 0.20^{\mathrm{a}}$ & $9.5 \pm 0.36^{\mathrm{a}}$ & $8.4 \pm 0.23^{\mathrm{a}}$ & $10.5 \pm 0.43^{\mathrm{b}}$ \\
\hline A. brasilense & $20.6 \pm 0.36^{\mathrm{b}}$ & $19.2 \pm 0.15^{\mathrm{d}}$ & $18.2 \pm 0.25^{\mathrm{d}}$ & $8.2 \pm 0.21^{\mathrm{a}}$ \\
\hline P. fluorescens & $27.4 \pm 0.42^{\mathrm{d}}$ & $15.2 \pm 0.38^{\mathrm{c}}$ & $9.3 \pm 0.26^{\mathrm{b}}$ & $12.6 \pm 0.40^{\mathrm{c}}$ \\
\hline $\begin{array}{l}\text { A. brasilense + } \\
\text { P. fluorescens }\end{array}$ & $25.3 \pm 0.70^{\mathrm{c}}$ & $14.3 \pm 0.35^{\mathrm{b}}$ & $9.7 \pm 0.21^{\mathrm{c}}$ & $8.3 \pm 0.49^{\mathrm{a}}$ \\
\hline
\end{tabular}

Average of three replicates; $\pm=$ SE; Differences between control and treated significant at $\mathrm{p}=0.01$ (Student's t-test) where superscript of control and treated are different; where superscript same, difference insignificant.

TABLE III

Effect of methods of application of single and mixed PGPR on the lateral root growth of groundnut plants.

\begin{tabular}{lllll}
\hline $\begin{array}{l}\text { PGPR } \\
\text { treatment }\end{array}$ & \multicolumn{2}{l}{ Lateral root growth (in mm) } & Seedling root dip & Foliar spray \\
\cline { 2 - 5 } Soil application & Seed treatment & $16.4 \pm 0.36^{\mathrm{a}}$ & $9.3 \pm 0.42^{\mathrm{a}}$ \\
\hline Control & $18.0 \pm 0.35^{\mathrm{a}}$ & $19.8 \pm 1.00^{\mathrm{c}}$ & $16.3 \pm 0.61^{\mathrm{a}}$ & $9.9 \pm 0.40^{\mathrm{b}}$ \\
A. brasilense & $20.5 \pm 0.43^{\mathrm{b}}$ & $17.5 \pm 0.51^{\mathrm{a}}$ & $23.8 \pm 0.57^{\mathrm{c}}$ & $16.1 \pm 0.35^{\mathrm{c}}$ \\
P. fluorescens & $21.9 \pm 0.87^{\mathrm{c}}$ & $18.7 \pm 0.90^{\mathrm{b}}$ & $18.0 \pm 0.46^{\mathrm{b}}$ & $15.7 \pm 0.40^{\mathrm{c}}$ \\
A. brasilense + & $27.7 \pm 0.66^{\mathrm{d}}$ & $22.9 \pm 0.82^{\mathrm{d}}$ & & \\
\hline P. fluorescens & & & & \\
\hline
\end{tabular}

Average of three replicates; $\pm=$ SE; Differences between control and treated significant at $\mathrm{p}=0.01$ (Student's t-test) where superscript of control and treated are different; where superscript same, difference insignificant.

characteristic. Besides having nitrogen fixing ability, Azospirillum spp. secrete phytoharmones such as auxins, cytokinins and gibberellins. Still growing discovery of beneficial effects of Pseudomonas include i) plant growth promotion. ii) production of antifungal metabolites like phenazines, pyrrolnitrin, pyoluteorin, 2,4-diacetylphloroglucinol, antifungal cyclic lipopeptides such as viscosinamide and tensin, antifungal enzymes like chitinase and other lytic enzymes, siderophore and hydrogen cyanide production, all having direct effect on pathogens iii) induced systemic resistance against fungi, bacteria, virus, insects and nematodes which involves indirect effect on biotic stress factors. iv) Imparting 
TABLE IV

Effect of methods of application of single and mixed PGPR on the number of leaves in groundnut plants.

\begin{tabular}{lllll}
\hline PGPR & \multicolumn{2}{l}{ Number of leaves } & & \\
\cline { 2 - 5 } treatment & Soil application & Seed treatment & Seedling root dip & Foliar spray \\
\hline Control & $16.3 \pm 1.53^{\mathrm{a}}$ & $21.0 \pm 1.00^{\mathrm{b}}$ & $15.7 \pm 0.58^{\mathrm{a}}$ & $17.7 \pm 0.58^{\mathrm{a}}$ \\
A. brasilense & $16.0 \pm 1.00^{\mathrm{a}}$ & $18.0 \pm 1.00^{\mathrm{a}}$ & $15.3 \pm 0.58^{\mathrm{a}}$ & $25.0 \pm 1.73^{\mathrm{d}}$ \\
$\begin{array}{l}\text { P. fluorescens } \\
\text { A. brasilense }+\end{array}$ & $26.3 \pm 1.53^{\mathrm{c}}$ & $24.3 \pm 1.53^{\mathrm{c}}$ & $20.3 \pm 1.53^{\mathrm{b}}$ & $20.3 \pm 0.58^{\mathrm{c}}$ \\
P. fluorescens & $24.0 \pm 1.00^{\mathrm{b}}$ & $17.7 \pm 0.58^{\mathrm{a}}$ & $22.0 \pm 1.73^{\mathrm{c}}$ & $19.0 \pm 1.00^{\mathrm{b}}$ \\
\hline
\end{tabular}

Average of three replicates; $\pm=\mathrm{SE}$; Differences between control and treated significant at $\mathrm{p}=0.01$ (Student's t-test) where superscript of control and treated are different; where superscript same, difference insignificant.

TABLE V

Effect of methods of application of single and mixed PGPR on the number of branches in groundnut plants.

\begin{tabular}{|c|c|c|c|c|}
\hline \multirow{2}{*}{$\begin{array}{l}\text { PGPR } \\
\text { treatment }\end{array}$} & \multicolumn{4}{|c|}{ Number of branches } \\
\hline & Soil application & Seed treatment & Seedling root dip & Foliar spray \\
\hline Control & $3.7 \pm 0.58^{\mathrm{a}}$ & $4.7 \pm 0.58^{\mathrm{a}, \mathrm{b}}$ & $5.0 \pm 1.00^{\mathrm{a}, \mathrm{b}}$ & $4.3 \pm 0.58^{\mathrm{a}}$ \\
\hline A. brasilense & $3.7 \pm 0.58^{\mathrm{a}}$ & $4.3 \pm 0.58^{\mathrm{a}}$ & $4.7 \pm 0.58^{\mathrm{a}}$ & $5.7 \pm 0.58^{\mathrm{c}}$ \\
\hline P. fluorescens & $6.7 \pm 0.58^{\mathrm{b}}$ & $5.7 \pm 0.58^{\mathrm{b}, \mathrm{c}}$ & $5.3 \pm 0.58^{b}$ & $4.7 \pm 0.58^{\mathrm{a}, \mathrm{b}}$ \\
\hline A. brasilense + & $6.3 \pm 0.58^{\mathrm{b}}$ & $5.0 \pm 1.00^{\mathrm{b}}$ & $5.7 \pm 0.58^{\mathrm{b}}$ & $4.3 \pm 0.58^{\mathrm{a}}$ \\
\hline P. fluorescens & & & & \\
\hline
\end{tabular}

Average of three replicates; $\pm=\mathrm{SE}$; Differences between control and treated significant at $\mathrm{p}=0.01$ (Student's t-test) where superscript of control and treated are different; where superscript same, difference insignificant.

tolerance to abiotic stress like saline stress, v) Interaction of Pseudomonas with Rhizobium.

During evolution, plants have become associated with guilds of plant-growth-promoting rhizobacteria (PGPR), which raises the possibility that individual PGPR populations may have developed mechanisms to cointeract with one another on plant roots (Combes-Meynet et al. 2011). Rhizosphere microorganisms are not only influenced by inhibitory plant compounds but compounds of microbial origin involved in parasitism, antagonism, or competition (Bouwmeester et al. 2007, Couillerot et al. 2009). In addition, molecular signals i.e., low molecular weight compounds that are emitted by an organism and recognized by another at nanomolar to micromolar concentration, and that elicit a response in the latter (Hirsch et al. 2003, Bais et al. 2006) are also involved. These signals are important for the establishment of mutualistic and associative interactions between microorganisms and plant roots (Cooper 2007, Pothier et al. 2007). Most signaling phenomena studied in the case of multitrophic interactions involving PGPR concern the impact of i) root-secreted compounds on the selection of root-associated bacteria (Ramey et al. 2004) and the control of their plant-beneficial activities (Pothier et al. 2007, Rudrappa et al. 2008, Teplitski et al. 2000); ii) bacterial secondary metabolites, including phytohormones, on root growth and plant defense (Lambrecht et al. 2000, Pieterse et al. 2003); and iii) quorum-sensing pheromones in the regulation of microbe-microbe social relationships (Boyer et al. 2008, Daniels et 

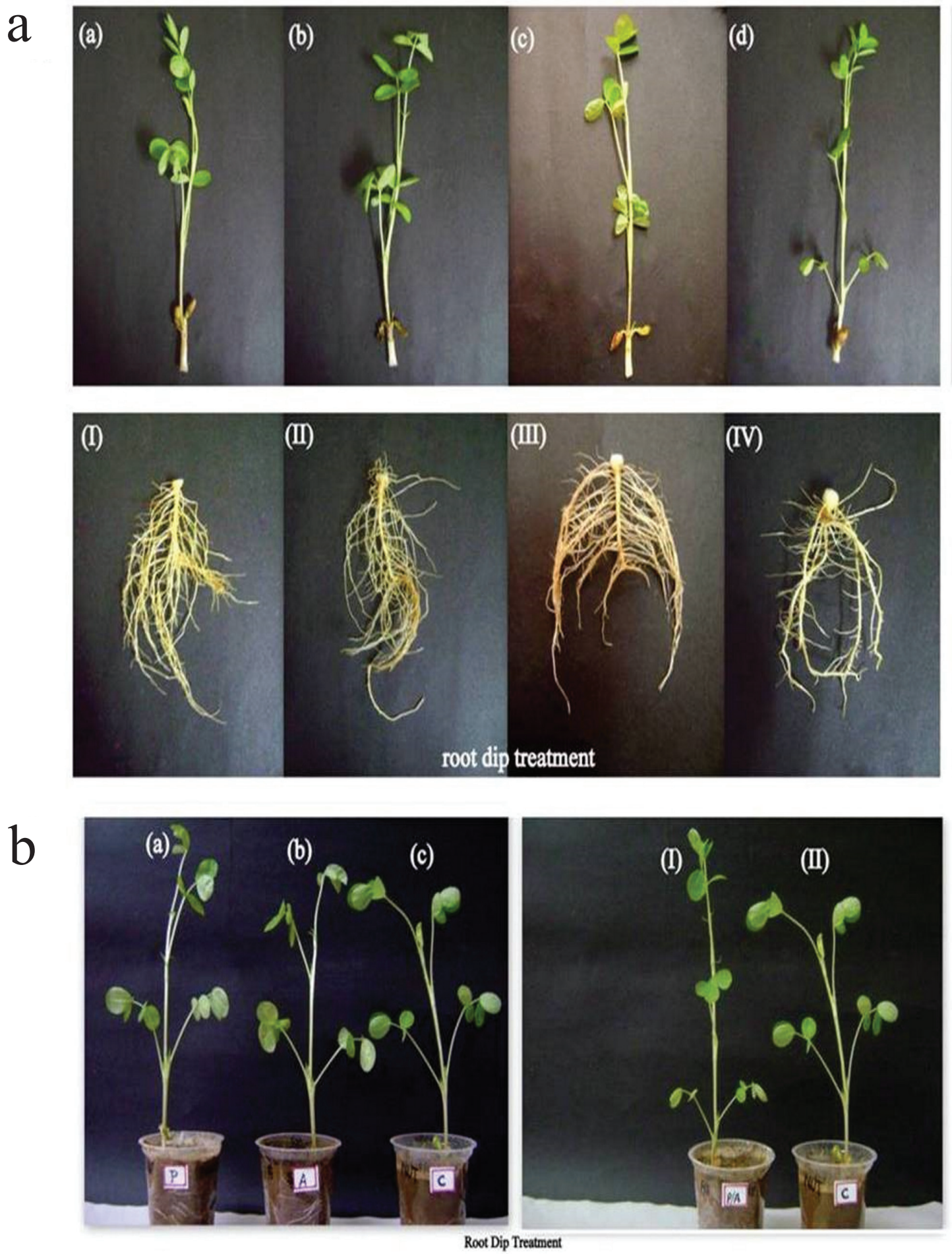

Figure 4 - Growth of groundnut plants under seedling root dip treatment with PGPR.

a. Root and shoot growth of groundnut under seedling root dip treatment with PGPR.

(a) and (I) - Control; (b) and (II) - A. brasilense; (c) and (III) - P. fluorescens; (d) and (IV) - A. brasilense and P. fluorescens.

b. Groundnut plants after seedling root dip treatment with PGPR.

(a) - P. fluorescens; (b) - A. brasilense; (c) - Control; (I) - A. brasilense and P. fluorescens; (II) - Control. 

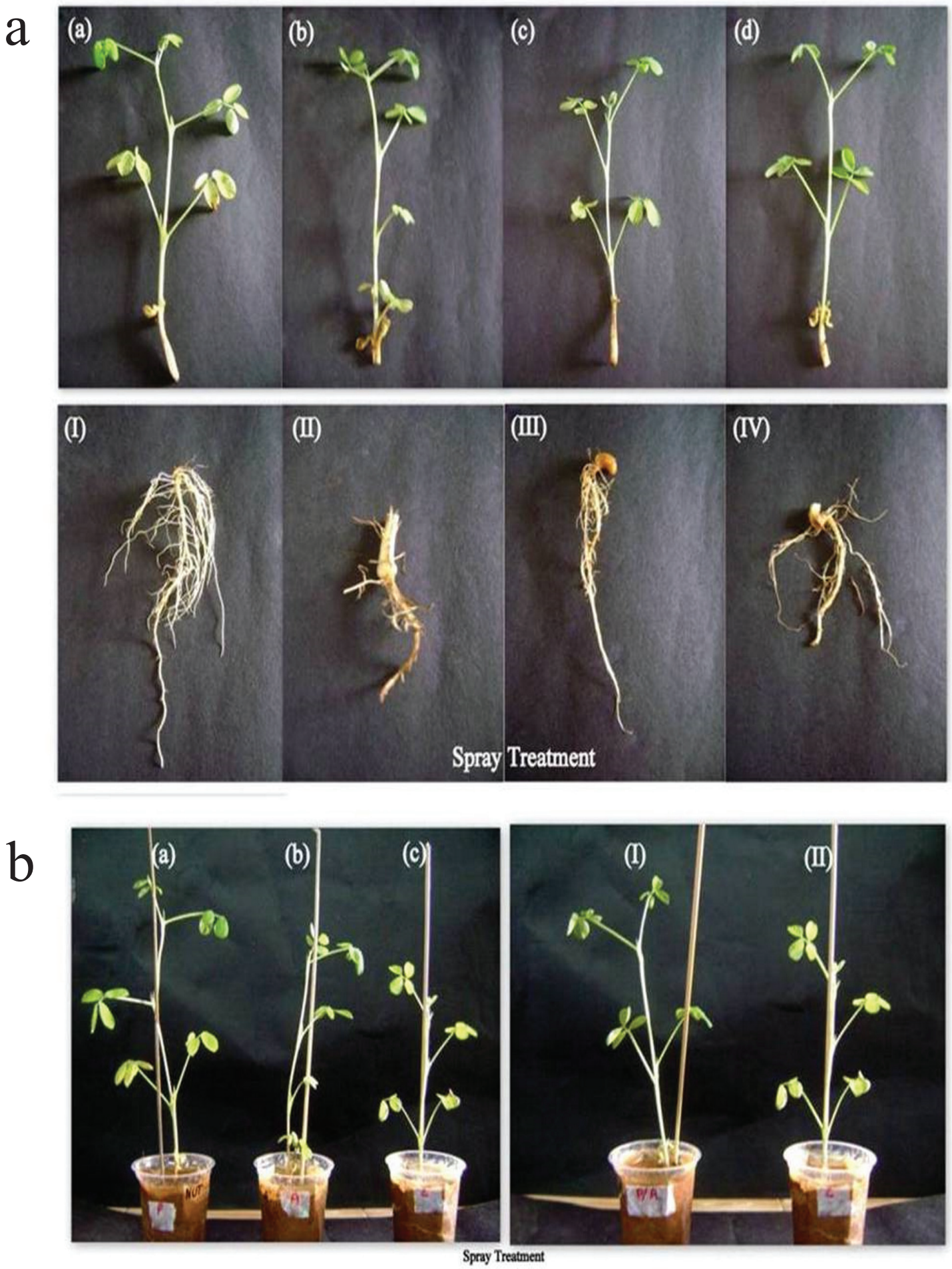

Figure 5 - Growth of groundnut plants under foliar spray treatment with PGPR.

a. Root and shoot growth of groundnut under foliar spray treatment with PGPR.

(a) and (I) - Control; (b) and (II) - A. brasilense; (c) and (III) - P. fluorescens; (d) and (IV) - A. brasilense and P. fluorescens.

b. Groundnut plants after foliar spray treatment with PGPR.

(a) - P. fluorescens; (b) - A. brasilense; (c) - Control; (I) - A. brasilense and P. fluorescens; (II) - Control. 
al. 2006). Because PGPR might have coevolved with plants, it could be that other types of signaling phenomena are also involved when considering the social relations between different types of PGPR colonizing the same roots (Wei and Zhang 2006). However, this possibility has been neglected so far.

A differential fluorescence induction promotertrapping approach based on flow cytometry was used to identify Azospirillum genes upregulated by 2,4-diacetyl phloroglucinol produced by Pseudomonas sp (Combes-Meynet et al. 2011). Four of the phytostimulation related genes (i.e., ppdC, flgE, nirK, and nifX-nifB) tended to be upregulated on wheat roots in the presence of $P$. fluorescens. Such studies have not been done in rice.

Our results obtained in the present study indicate that a similar or same mechanism might underpin the beneficial interactions between $P$. fluorescens and A. brasilense in promoting seedling growth of groundnut. It is very important to understand the interaction among these two PGPR microbes at the molecular level to have a fundamental clue on the observed synergism in groundnut plant growth promotion. This can help design better consortia of microbes (with $P$. fluorescens and $A$. brasilense as members) and in a better formulation for application in groundnut and later in other agricultural crops.

\section{ACKNOWLEDGMENTS}

The support and encouragement of the management of VIT University, Vellore, India is gratefully acknowledged.

\section{REFERENCES}

ASHRAFUZZAMAN M, HOSSEN FA, ISMAIL MR, ISMAIL MDR, HOQUE MDA, SHAIDULLAH SM AND MENON S. 2009. Efficiency of plant growth promoting rhizobacteria (PGPR) for the enhancement of rice growth. Afr J Biotechnol 8: 1247-1252.
BABU S. 2011. Pseudomonas fluorescens mediated biocontrol: from lap to lab to land. Biotechnology J 6: 488-491.

BAIS HP, WEIR TL, PERRY LG, GILROY S AND VIVANCO JM. 2006. The role of root exudates in rhizosphere interations with plants and other organisms. Annu Rev Plant Biol 57: 233-266.

BLOEMBERG GV AND LUGTENBERG BJJ. 2001. Molecular basis of plant growth promotion and biocontrol by rhizobacteria. Curr Opin Plant Biol 4: 343-350.

BOUWMEESTER HJ, ROUX C, LOPEZ-RAEZ JA AND BÉCARD G. 2007. Rhizosphere communication of plants, parasitic plants and AM fungi. Trends Plant Sci 12: 224230.

BOYER M, BALLY R, PERROTTO S, CHAINTREUIL C AND WISNIEWSKI-DYE F. 2008. A quorum-quenching approach to identify quorum-sensing regulated functions in Azospirillum lipoferum. Res Microbiol 159: 699-708.

COMBES-MEYNET E, POTHIER JF, MOENNE-LOCCOZY AND PRIGENT-COMBARET C. 2011. The Pseudomonas secondary metabolite 2,4-diacetylphloroglucinol is a signal inducing rhizoplane expression of Azospirillum genes involved in plant-growth promotion. Mol Plant-Microbe Interact 24: 271-284.

COOPER JE. 2007. Early interactions between legumes and rhizobia: Disclosing complexity in a molecular dialogue. J Appl Microbiol 103: 1355-1365.

COUILLEROT O, PRIGENT-COMBARET C, CABALLERO-MELLADO J AND MOËNNE-LOCCOZ Y. 2009. Pseudomonas fluorescens and closely-related fluorescent pseudomonads as biocontrol agents of soilborne phytopathogens. Lett Appl Microbiol 48: 505-512.

DANIELS R ET AL. 2006. Quorum signal molecules as biosurfactants affecting swarming in Rhizobium etli. Proc Natl Acad Sci USA 103: 14965-14970.

HIGA T. 1994. Effective microorganisms: A new dimension for nature Farming. p. 20-22. In: Parr JF, Hornick SB and Simpson ME (Eds), Proceedings of the Second International Conference on Kyusei Nature Farming. US Department of Agriculture, Washington DC, USA.

HIRSCH AM, BAUER WD, BIRD DM, CULLIMORE J, TYLER B AND YODER JI. 2003. Molecular signals and receptors: Controlling rhizosphere interactions between plants and other organisms. Ecology 84: 858-868.

LAMBRECHT M, OKON Y, BROEK AV AND VANDERLEYDEN J. 2000. Indole- 3-acetic acid: A reciprocal signalling molecule in bacteria-plant interactions. Trends Microbiol 8: 298-300.

PIETERSE CMJ, VAN PELT JA, VERHAGEN VWM, TON J, VAN WEES SCM, LEON-KLOOSTERZIEL KM AND VAN LOON LC. 2003. Induced systemic resistance by plant growth-promoting rhizobacteria. Symbiosis 35: 3954. 
POTHIER JF, WISNIEWSKI-DYE F, WEISS-GAYET M, MOENNE-LOCCOZ Y AND PRIGENT-COMBARET C. 2007. Promoter-trap identification of wheat seed extract-induced genes in the plant-growth-promoting rhizobacterium Azospirillum brasilense Sp245. Microbiology 153: 3608-3622.

RAMEY BE, KOUTSOUDIS M, VON BODMAN SB AND FUQUA C. 2004. Biofilm formation in plant-microbe associations. Curr Opin Microbiol 7: 602-609.

RUDRAPPA T, BIEDRZYCKI ML AND BAIS HP. 2008. Causes and consequences of plant-associated biofilms. FEMS Microbiol Ecol 64: 153-166.

TEPLITSKI M, ROBINSON JB AND BAUER WD. 2000. Plants secrete substances that mimic bacterial $\mathrm{N}$-acyl homoserine lactone signal activities and affect population density-dependent behaviors in associated bacteria. Mol Plant-Microbe Interact 13: 637-648.

VIDHYASEKARAN P, RABINDRAN R, MUTHAMILAN M, NAYAR K, RAJAPPAN K, SUBRAMANIAN N AND VASUMATHI K. 1997. Development of a powder formulation of Pseudomonas fluorescens for control of rice blast. Plant Path 46: 291-297.

WEI HL AND ZHANG LQ. 2006. Quorum-sensing system influences root colonization and biological control ability in Pseudomonas fluorescens 2P24. Antonie Leeuwenhoek 89: 267-280. 